\title{
Effect of prostaglandin F-2 $\alpha$ on steroidogenesis by porcine corpora lutea
}

\author{
J. S. Torday, C. R. Jefcoate* and N. L. First $\dagger$ \\ Department of Neonatology, Harvard Medical School, Boston, Massachusetts 02115; \\ * Department of Pharmacology, University of Wisconsin, Madison, Wisconsin 53706; and \\ †Department of Meat and Animal Science, University of Wisconsin, Madison, Wisconsin \\ 53706, U.S.A.
}

\begin{abstract}
Summary. The relationship between luteal cholesterol bound to cytochrome $\mathrm{P}^{450} \mathrm{scc}_{\text {scc }}$ enzyme and progesterone production was studied in the pig. Luteal progesterone peaked on Day 10 of the oestrous cycle, declined slowly until Day 13 and then precipitously between Days 13 and 14 . The $\mathrm{P}_{450}$ scc was nearly saturated with cholesterol between Days 4 and 13, but changed abruptly by Day 14 to a partly depleted state which persisted until Day 16. Total $\mathbf{P 4 5 0}$ scc did not decline significantly until Day 17. There was no change in cholesterol esterase activity in a $105000 \mathrm{~g}$ supernatant or in total mitochondrial cholesterol during this period.

Intravenous administration of PGF-2 $\alpha$ to hysterectomized gilts resulted in a rapid depletion of cholesterol from $\mathrm{P}^{450} \mathrm{scc}_{\mathrm{sc}}$ with a half-life of about $2 \mathrm{~h}$. The new

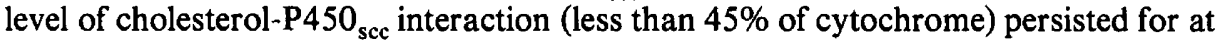
least $36 \mathrm{~h}$ after treatment. This was paralleled by declines in plasma and luteal progesterone.

These results are compatible with the hypothesis that PGF- $2 \alpha$ provokes a decline in progesterone secretion around Day 13 by first decreasing the supply of cholesterol to $\mathbf{P} 450_{\text {sce }}$.
\end{abstract}

\section{Introduction}

Cyclic regression of corpora lutea is under uterine control in swine (Horton \& Poyser, 1976) because regression of the corpora lutea does not occur after hysterectomy (du Mesnil du Buisson, 1961; Moeljono, Bazer \& Thatcher, 1976) and prostaglandin (PG) F-2 $\alpha$, the suspected uterine luteolytic agent, causes luteolysis in hysterectomized gilts (Moeljono et al., 1976). Levels of PGF-2 $\alpha$ in the uterine vein increase just before Day 13 in a series of short-duration spikes and peak between Days 13 and 14 of the oestrous cycle, just before functional luteolysis (Gleeson \& Thorburn, 1973; Gleeson, Thorburn \& Cox, 1974). Peripheral plasma progesterone normally peaks at Day 10, declines slowly to Day 13 and rapidly between Days 13 and 15 to levels that are barely detectable (Diehl \& Day, 1974; Halford, Wetteman, Turman \& Omtvedt, 1975; Guthrie \& Polge, 1976; Guthrie \& Rexroad, 1978). This later and rapid decline in progesterone is considered indicative of functional luteolysis. Exogenous PGF- $2 \alpha$ will cause luteolysis of corpora lutea of pregnancy (Diehl \& Day, 1974; Moeljono et al., 1976; Coggins, Van Horn \& First, 1977) or of corpora lutea whose lifespan has been prolonged by hysterectomy (Moeljono et al., 1976) or exogenous oestrogen (Kraeling, Barb \& Davis, 1975; Guthrie, 1975). Corpora lutea of the porcine oestrous cycle are refractory to PGF-2 $\alpha$ until Day 12 (Diehl \& Day, 1974; Guthrie \& Polge, 1976). Indomethacin, which inhibits PG synthesis, will prevent luteolysis at the end of pregnancy and this effect is overcome by exogenous PGF-2 $\alpha$, providing proof that at that stage in the life of the corpora lutea PGF-2 $\alpha$ is the luteolytic agent (Nara \& First, 1977). A comparable in-vivo study has not been reported for corpora lutea of the oestrous cycle. 
The mechanism of action of PGF-2 $\alpha$ remains unclear. In vitro, PGF-2 $\alpha$ terminates the production of progesterone by porcine corpora lutea and incubated luteal slices are protected from PGF-2 $\alpha$ by the addition of LH but not oestradiol (Watson \& Maule Walker, 1978). In other species, a direct antagonism of LH-binding by PGF- $2 \alpha$ has been shown to correlate with reduced cAMP stimulation (Behrman, Grinwich \& Hichens, 1976) and PGF-2 $\alpha$ receptors have been demonstrated in corpora lutea (Powell, Hammarstrom \& Samuelsson, 1975).

The rate-limiting step in luteal steroidogenesis, and that of all steroidogenic tissues, is the conversion of cholesterol to pregnenolone (Burstein \& Gut, 1971). This reaction is catalysed by the mitochondrial cytochrome $\mathrm{P} 450$ side-chain cleavage enzyme $\left(\mathrm{P}_{50} \mathrm{scc}_{\mathrm{sc}}\right)$ (Simpson \& Boyd, 1967). Recent investigations of the mechanisms controlling steroidogenesis have implicated control of this process by a labile protein which facilitates cholesterol transport in the adrenal cortex (Jefcoate, 1975) and the corpus luteum (Hermier, Combarnous \& Jutisz, 1971) and which has enhanced activity after hormonal stimulation. If stimulation of steroid production can result from an increase in enzyme-associated cholesterol, one of the early events to affect progesterone production at the time of luteolysis may be a cessation of the cholesterol transport with a consequent decrease in $P 450_{\text {scc }}$-cholesterol complex. To test this hypothesis, the association of cholesterol with mitochondrial $\mathrm{P}^{450_{\text {scc }}}$ and the effect of PGF-2 $\alpha$ on this association were studied during the oestrous cycle of the pig.

\section{Materials and Methods}

Crystalline PGF- $2 \alpha$ tromethamine salt was a gift from Dr J. Lauderdale, Upjohn Company, Kalamazoo, Michigan; it was routinely dissolved in a $0.9 \%$ sodium chloride $(0.9 \mathrm{mg} / \mathrm{ml})$ immediately before use. $\left[1,2,6,7-{ }^{3} \mathrm{H}\right]$ Progesterone (sp. act. $103 \cdot 7 \mathrm{Ci} / \mathrm{mmol}$ : New England Nuclear, Boston, Massachusetts) was repurified using LH-20 microcolumns with the solvent system heptane: chloroform : ethanol : water (200:200:1: saturating, by vol.) (Murphy, 1970). Cholestane and cholesterol standards were purchased from Sigma, St. Louis, Missouri. Fluothane was obtained from Ayerst Laboratories, New York. Surital (sodium thiamylal, 4\% solution) was purchased from Parke-Davis.

\section{Experimental animals}

Yorkshire gilts, 5-7 months of age, were observed daily for behavioural oestrus using teaser boars; they were allowed to complete at least one oestrous cycle. The first day of the oestrous cycle (about 21 days) was designated Day 1.

Cyclic pigs. Four gilts were stunned by a captive bolt pistol and slaughtered by exsanguination on each of Days 4, 7,10,13,14,15 and 16 of the oestrous cycle. The ovaries were removed by mid-ventral laparotomy, placed in ice-cold $0.9 \% \mathrm{NaCl}$ within $5 \mathrm{~min}$ of slaughter and the corpora lutea were dissected free of stromal tissue. Aliquots of luteal tissue were weighed for assay of progesterone content and frozen at $-15^{\circ} \mathrm{C}$ until analysed; tissue to be analysed for $\mathrm{P}^{450_{\mathrm{scc}}}$ was put in ice-cold $0.25 \mathrm{M}$-sucrose and assayed as described below.

Pregnant pigs. After mating on Day 1, 3 pigs were slaughtered on each of Days 7, 16, 17 and 20. The uteri were flushed with saline in order to examine the contents for the presence of embryos and establish that the animals were pregnant.

Hysterectomized, PGF-2a-treated pigs. After being fasted for 24 h 18 gilts were hysterectomized between Days 5 and 7 of the oestrous cycle. Surital was administered through the ear vein to induce anaesthesia and each gilt was maintained on 4\% Fluothaneoxygen : nitrous oxide (2:1 v/v) during surgery (Dziuk, Phillips \& Graber, 1964). The uterus was removed by mid-ventral laparotomy.

On the morning of Day 13 a sample of blood was obtained through a polyethylene cannula 
(which had been inserted into the jugular vein $24 \mathrm{~h}$ previously) and $5 \mathrm{mg}$ PGF-2 $\alpha$ were administered through the cannula which was then flushed with $5 \mathrm{ml}$ heparinized saline (100 $\mathrm{U} / \mathrm{ml} 0.9 \% \mathrm{NaCl}$ ). Blood was taken at the intervals indicated in Table 1 and the plasma was stored at $-15^{\circ} \mathrm{C}$ until assayed for progesterone. At $0,2,4,6,12$ and $36 \mathrm{~h}$ after PGF-2 $\alpha$ administration, 3 gilts were slaughtered. The ovaries were collected and processed as described above for determination of progesterone and $\mathrm{P}^{450} 0_{\text {scc }}$ enzyme in the corpora lutea.

\section{Progesterone determination}

Progesterone in plasma and tissue was assayed using the technique of Staigmiller, First \& Casida (1974). The direct radioimmunoassay detected total progestagens, but the antiserum used by Staigmiller et al. (1974) shows cross-reactivity only with pregnenolone and this is $<10 \%$. The lower limit of sensitivity of the assay is less than $2 \mathrm{ng} / \mathrm{ml}$ with a standard deviation of approximately $1 \mathrm{ng} / \mathrm{ml}$. Separation by chromatography and assay of progesterone alone provided the same values as non-chromatographed samples, indicating that progesterone alone was assayed.

Assay of $P 450_{\text {scc }}$

Corpora lutea were freed of adhering tissue, quartered in $0.25 \mathrm{M}$-sucrose (approximately 200 $\mathrm{mg} / \mathrm{ml}$ ) and homogenized by 3 passes of a motor driven teflon pestle in a glass homogenizer; nuclei and cell debris were removed by centrifugation at $2000 \mathrm{~g}$ for $10 \mathrm{~min}$. Mitochondria were subsequently pelleted from the supernatant by centrifuging at $10000 \mathrm{~g}$ for $10 \mathrm{~min}$. The mitochondria were suspended in $1 \mathrm{ml} 0.25 \mathrm{M}$-sucrose. Optical difference spectra were determined at $32^{\circ} \mathrm{C}$ by diluting $0.1 \mathrm{ml}$ mitochondrial homogenate with $0.9 \mathrm{ml}$ BSA-buffer $(0.25 \mathrm{M}$-sucrose, $0.5 \%$ bovine serum albumin, $20 \mathrm{mM}-\mathrm{KCl}, 15 \mathrm{mM}$-triethanolamine, $10 \mathrm{~mm}$ potassium phosphate, $0.5 \mathrm{~mm}-\mathrm{MgCl}_{2}$, and $0.1 \mathrm{~mm}$-EDTA, $\mathrm{pH} 6.2$ ). The extent of cholesterol$\mathrm{P}^{450} 0_{\text {scc }}$ complex formation was measured by the reverse-Type I spectral response to pregnenolone ( $10 \mu \mathrm{g}$ in acetone) using a DW 2 spectrophotometer in the dual-wavelength mode set to measure $\Delta \mathrm{A}(420-390 \mathrm{~nm})$ (Jefcoate, Simpson \& Boyd, 1974). Unbound P450 ${ }_{\text {scc }}$ was measured by the Type I spectral response to a single saturating addition of 25hydroxycholesterol $(2.5 \mu \mathrm{g})$. Total cytochrome P450 was measured by the reduced-carbon monoxide $(\mathrm{CO})$ difference spectrum, using an extinction coefficient $\Delta \varepsilon(450-490 \mathrm{~nm})=91$ $\mathrm{mm}^{-1} \mathrm{~cm}^{-1}$. The sum of steroid responses was used to quantitate specifically cytochrome $\mathrm{P}^{450_{\mathrm{scc}}}$, as previously discussed with respect to hormonal activation of cytochrome $\mathrm{P}^{450_{\mathrm{scc}}}$ in the adrenal gland (Hermier et al., 1971). In determining the proportion of $\mathrm{P} 450_{\mathrm{scc}}$ bound to cholesterol, we assumed that all the $\mathrm{P}^{4} \mathrm{SO}_{\text {scc }}$ is accounted for by these responses. However, according to accepted extinction coefficients (Jefcoate, 1975), about $20 \%$ of the cytochrome $\mathrm{P} 450$ does not respond to the steroids. This fraction may not be $\mathrm{P}^{450} \mathrm{scc}_{\text {sc }}$ or may be $\mathrm{P} 450_{\text {scc }}$ that does not undergo a spectral change when binding cholesterol or an analogue (Jefcoate, 1975). The term 'percentage bound' therefore refers to responsive $\mathrm{P}^{450_{\text {sce. }}}$

\section{Other determinations}

Mitochondrial protein was estimated by the method of Lowry, Rosebrough, Farr \& Randall (1951).

Mitochondrial cholesterol was isolated from mitochondria by the method of Simpson, Jefcoate, Brownie \& Boyd (1972) and quantitated by gas chromatography (Ishikawa, Macgee \& Morrison, 1974). Under these conditions, the retention times for cholesterol and cholestane were 5 and $15 \mathrm{~min}$, respectively. 
Cholesterol esterase assay. The $105000 \mathrm{~g}$ supernatant from each homogenate of corpora lutea was deionized on G25 Sephadex to remove endogenous cyclic AMP and ATP. The eluate was made up to a volume of $10 \mathrm{ml}$ in Tris-chloride $(50 \mathrm{~mm}), \mathrm{MgCl}_{2}(10 \mathrm{mM}), \mathrm{pH} \mathrm{7.4}$. Cholesterol esterase assays were carried out on this solution by the method of Trzeyciak \& Boyd (1974). Activities were converted to units per $400 \mathrm{mg}$ luteal tissue.

\section{Statistical analysis}

Data were analysed by Duncan's multiple-range test (Steele \& Torrie, 1960) or the StudentNewman-Kuels test (Zar, 1974) after analysis of variance. Linear regression parameters were calculated by the method of least squares.

\section{Results}

Treatment of hysterectomized pigs with PGF-2 $\alpha$ resulted in a significant $(P<0.01)$ decline in plasma progesterone within $4 \mathrm{~h}$; these levels continued to decline for up to $6 \mathrm{~h}$, but the level at this time (50\% of the initial level) persisted for up to $36 \mathrm{~h}$. A similar fall in the progesterone content of corpora lutea was observed within $4 \mathrm{~h}$ of treatment $(P<0.01$, Text-fig. 1). Analysis of the percentage of $\mathrm{P}^{450}$ scc bound to cholesterol after PGF-2 $\alpha$ treatment revealed that there was a marked decline within $2 \mathrm{~h}(P<0.01)$. The value reached at $6 \mathrm{~h}$ after treatment was maintained for at least $36 \mathrm{~h}$. There was no significant change in total $\mathbf{P 4 5 0}_{\text {scc }}$ in this period $(P>0.25)$. The decline in plasma progesterone and the percentage of $P 450_{\text {scc }}$ complexed by cholesterol were highly correlated (coefficient of correlation, $r=0.65, P<0.01$ ).

In a preliminary experiment the $\mathrm{P}^{4} 5 \mathrm{O}_{\text {scc }}$-associated cholesterol of the adrenal cortex of animals treated with PGF- $2 \alpha$ was studied to determine whether the effect of PGF-2 $\alpha$ was tissue specific. The percentage of $\mathrm{P}^{4} \mathrm{SO}_{\mathrm{scc}}$ bound to cholesterol did not change in this tissue.

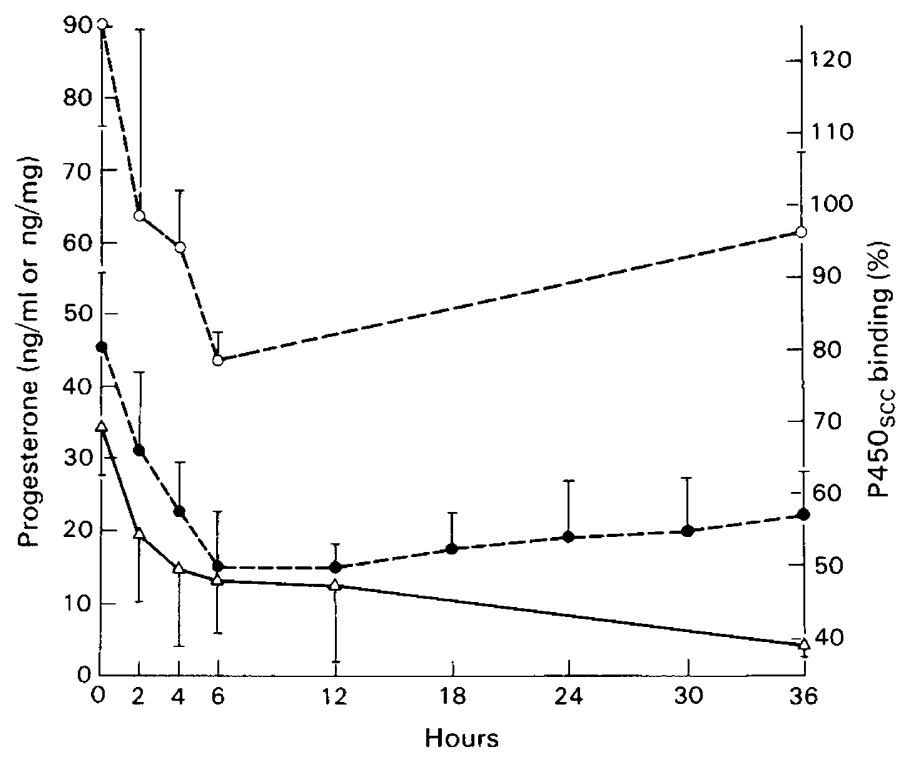

Text-fig. 1. Plasma progesterone (O), luteal progesterone $(\mathrm{O})$ and $\mathrm{P} 450_{\text {scc }}$ bound to cholesterol $(\triangle)$ following injection of PGF- $2 \alpha$ tromethamine salt $(5 \mathrm{mg})$ to hysterectomized pigs on Day 13 of the oestrous cycle. Each point represents the mean \pm s.d. of 2-18 pigs (plasma progesterone), 2-6 pigs (luteal progesterone) or 3 pigs ( $\mathrm{P}^{450_{\text {scc }}}$ binding). 
The response of $\mathrm{P}^{450_{\text {scc }}}$ in both intact and disrupted mitochondria to pregnenolone and 25 hydroxycholesterol are compared with reduced-CO difference spectra in Table 1. The sum of the steroid responses is constant within experimental error $(\sim 5-10 \%)$, irrespective of the relative individual responses to the steroids and was a mean of $1.09 \pm 0.11$ (s.d.) times the magnitude of the reduced $\mathrm{CO}$ response. The total steroid response was used as a measure of $\mathrm{P} 450_{\mathrm{scc}}$ content $\left(\Delta \varepsilon=105 \mathrm{mM}^{-1} \mathrm{~cm}^{-1}\right.$ ) rather than the reduced $\mathrm{CO}$ response which measures all $\mathrm{P} 450$.

Table 1. Correlations between steroid-induced spectral responses and reduced-CO difference spectra for $\mathrm{P}^{4} 50_{\text {scc }}$ in intact and disrupted (by freezing and thawing) mitochondria from pig corpora lutea

\begin{tabular}{|c|c|c|c|c|c|c|}
\hline \multirow[b]{2}{*}{ Day } & \multirow[b]{2}{*}{ Treatment } & \multirow[b]{2}{*}{$\begin{array}{l}25 \text {-Hydroxy } \\
\text { cholesterol* }^{*}\end{array}$} & \multicolumn{3}{|c|}{ Absorbance changes $\times 10 / \mathrm{mg}$ protein } & \multirow{2}{*}{$\begin{array}{l}\text { Ratio } \\
\text { Total steroid: } \\
\text { reduced CO }\end{array}$} \\
\hline & & & Pregnenolone ${ }^{\dagger}$ & $\begin{array}{l}\text { Total } \\
\text { steroid }\end{array}$ & $\begin{array}{c}\text { Reduced } \\
\text { CO } \ddagger\end{array}$ & \\
\hline 13 & & 10 & 22 & 32 & 25 & $1 \cdot 28$ \\
\hline 13 & & 8 & 25 & 33 & 32 & 1.03 \\
\hline 13 & & 10 & 29 & 39 & 38 & 1.03 \\
\hline 13 & & 9 & 22 & 31 & 33 & 0.94 \\
\hline 13 & $\begin{array}{c}\text { Hysterectomy } \\
\text { (Days 5-7) + PGF-2 } \alpha \\
\text { (4 h) }\end{array}$ & 25 & 15 & 40 & 36 & $1 \cdot 11$ \\
\hline 15 & & 27 & 22 & 49 & 43 & $1 \cdot 13$ \\
\hline 15 & Mitochondria disrupted & 8 & 41 & 49 & 43 & $1 \cdot 13$ \\
\hline
\end{tabular}

\footnotetext{
* Type I response $\triangle \mathrm{A}(390-420 \mathrm{~nm})$.

+ Reverse type I response $\Delta \mathrm{A}(420-390 \mathrm{~nm})$.

$\ddagger \triangle \mathrm{A}(450-490 \mathrm{~nm})$.
}

Disruption of mitochondria from Day 15 cyclic animals caused a decrease in the response to 25-hydroxycholesterol and an increase in the response to pregnenolone such that the final values were close to those in intact mitochondria from Day 13 animals. (When a more vigorous disruption by sonication has been used on rat adrenal mitochondria the response to 25-hydroxycholesterol was completely removed and it seems likely that the residual response here is due to incomplete disruption.) This shows that cholesterol moves to $\mathrm{P} 450_{\text {scc }}$ when the mitochondria are disrupted and that there are constraints on cholesterol movement in the Day 15 mitochondria which are greater than those in Day 13 mitochondria. In addition, hormonal effects on cholesterol binding to $\mathrm{P}^{450_{\text {scc }}}$ are dependent on the presence of intact mitochondria, as has been reported for adrenal mitochondria (Jefcoate \& Orme-Johnson, 1975).

As shown in Text-fig. 2, the progesterone content of the corpora lutea of the oestrous cycle increased significantly between Days 7 and $10(P<0.01)$ to $136.5 \mathrm{ng} / \mathrm{ml}$ at Day 10 . There was a small decline from Day 10 to Day $13(100.2 \mathrm{ng}, P>0.05)$ followed by a precipitous drop between Days 13 and 14 to $47.7 \mathrm{ng} / \mathrm{ml}(P<0.01)$. The progesterone content of the corpora lutea was not significantly different between Days 14 and $16(P>0.05)$. The luteal progesterone concentrations in the pregnant animals on Days 16,17 and 20 were not significantly different from that on Day 13 of the oestrous cycle $(P>0 \cdot 25)$.

Total $\mathrm{P} 50_{\text {scc }}$ per $400 \mathrm{mg}$ wet luteal tissue (Text-fig. 3) rose 3 -fold $(P<0.01)$ between Days 4 and 14 of the oestrous cycle, remained at a plateau on Days 14, 15 and 16, and declined on Day 17. Total $\mathrm{P} 450_{\text {scc }}$ in the corpora lutea from Days 16, 17 and 20 of pregnancy remained high and at a level similar to that seen on Days 13-16 of the cycle. Unlike corpora lutea of the oestrous cycle, there was no decline in total $\mathbf{P} 450_{\text {scc }}$ between Days 17 and 20. The amount of total $\mathrm{P} 450_{\text {scc }}$ in the corpora lutea of Day 7 animals was not affected by pregnancy $(P>0.25)$. This pattern was virtually the same whether it was expressed as a function of luteal mass or mitochondrial protein. 


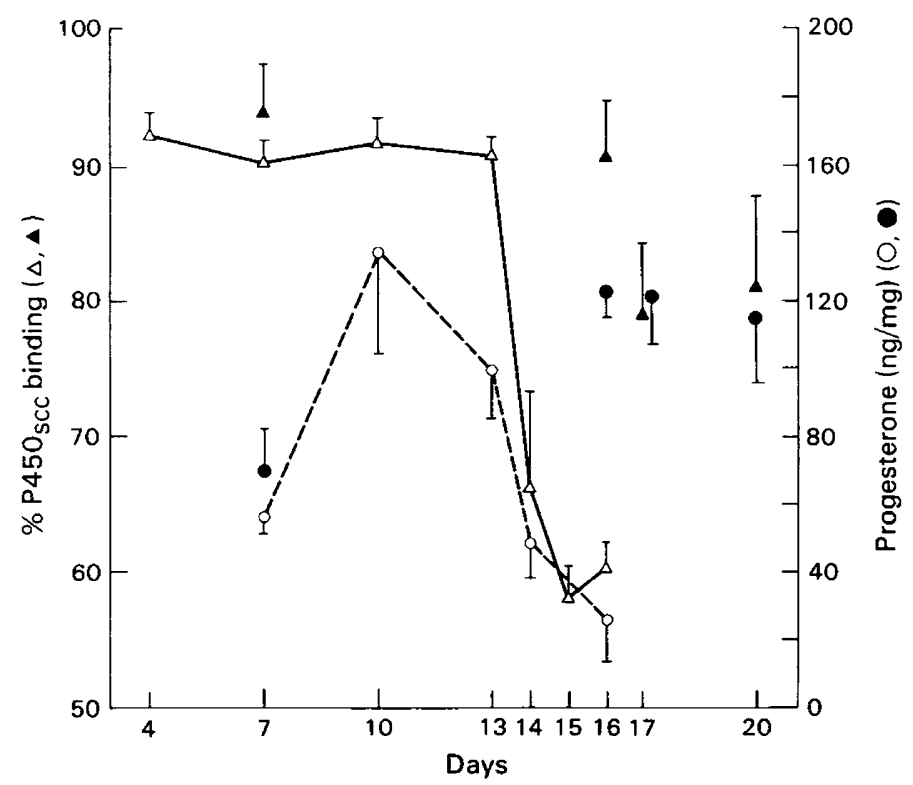

Text-fig. 2. Comparison of luteal progesterone in cyclic (O) and pregnant (O) pigs with cytochrome $\mathrm{P} 450_{\text {scc }}$ associated with cholesterol in cyclic $(\Delta)$ and pregnant $(\Delta)$ animals. Values are mean \pm s.d. for 4 (cyclic) and 3 (pregnant) pigs. Day $1=1$ st day of oestrus.

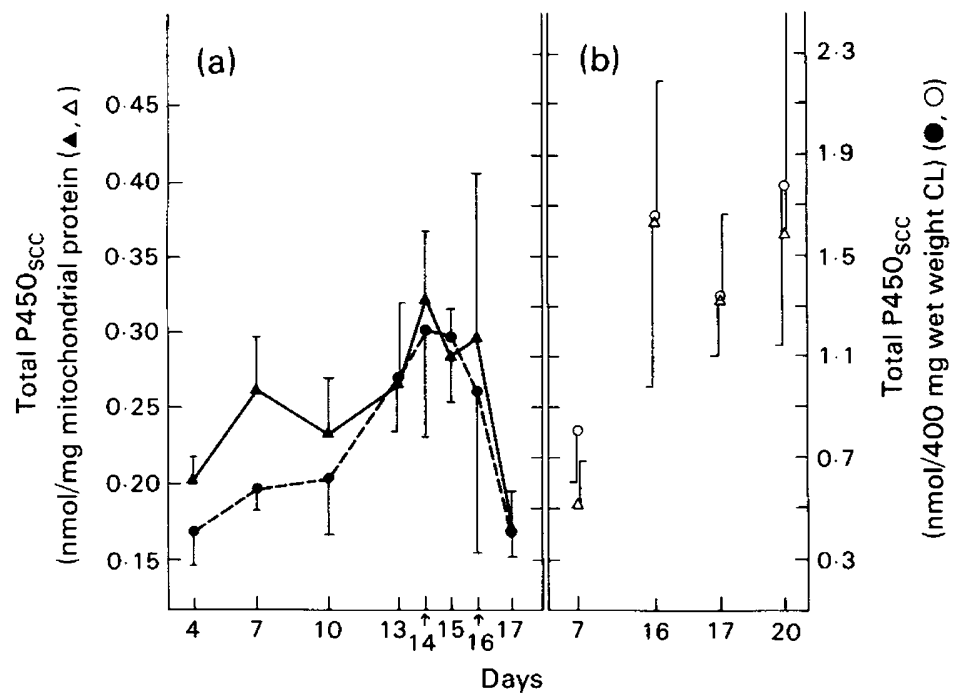

Text-fig. 3. Total luteal cytochrome $\mathrm{P}^{450_{\text {scc }}}$ in (a) cyclic and (b) pregnant animals. Each point represents the mean \pm s.d. of 4 (cyclic) and 3 (pregnant) animals. Day $1=1$ st day of oestrus.

Between Days 4 and 13, P450 ${ }_{\text {scc }}$ was at least $90 \%$ saturated with cholesterol (Text-fig. 2). Between Days 13 and 14, there was a precipitous fall in the percentage of $\mathrm{P}^{4} \mathrm{O}_{\mathrm{scc}}$ which was associated with cholesterol, resulting in the establishment of a new equilibrium on Days 15 and 16. A significant fall in $\mathbf{P} 450_{\text {scc }}$-associated cholesterol occurred $72 \mathrm{~h}$ before a change in total $\mathrm{P}_{450}$ scc became significant on Day 17 (Text-fig. 3). This depletion of cholesterol from $\mathrm{P} 450_{\mathrm{scc}}$ in the cyclic animals was not observed for tissue from any of the pregnant animals.

The quantity of total mitochondrial cholesterol did not change significantly during the 
oestrous cycle $(r=0)$. The differences in luteal cholesterol esterase activity (Text-fig. 4) were as great between individuals on any day studied as they were between days; despite this, there was a correlation between the decline in cholesterol esterase activity and the day of the cycle $(r=$ $0.45, P<0.05)$.

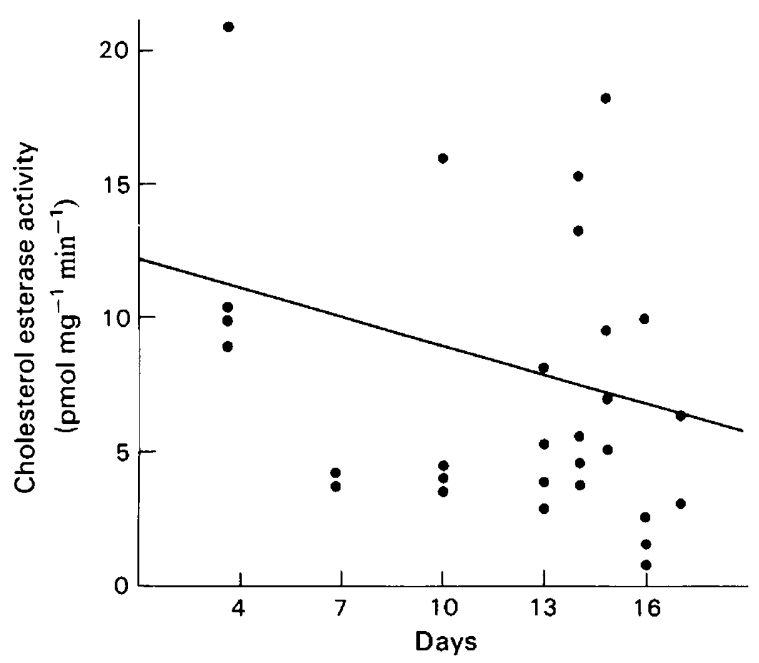

Text-fig. 4. Luteal cholesterol esterase activity during the pig oestrous cycle. Each point represents the value for one animal. The equation for the linear regression line is $y=11.8-0.4$ $x(r=0.45)$.

\section{Discussion}

There is considerable evidence that, in the adrenal gland, transference of cholesterol to $\mathrm{P}^{4} \mathrm{~s}_{\mathrm{scc}}$ is the rate-limiting step and is hormonally activated (Garren, Gill, Masni \& Watson, 1971; Jefcoate, 1975). Intracellular cholesterol availability is enhanced by activation of cholesterol esterase by a cAMP-dependent protein kinase (Trzeyciak \& Boyd, 1974). However, considerable evidence also indicates that major control over $\mathrm{LH}$ - and $\mathrm{ACTH}$-activated steroidogenesis is exerted via a labile protein which is sensitive to protein synthesis inhibitors and which facilitates cholesterol movement to $\mathrm{P}^{4} 0_{\text {scc }}$ within the mitochondria (Garren et al., 1971; Hermier et al., 1971). Likewise, in these studies, there was no correlation between the fall in progesterone content of the corpora lutea and the total mitochondrial cholesterol concentration. Cholesterol esterase activity also failed to correlate with the progesterone content of corpora lutea although there was a slight decline in this activity towards the end of the cycle.

Functional luteolysis in the sow in association with a rise in PGF- $2 \alpha$ has generally been observed to start at Day 13 of the oestrous cycle (Gleeson \& Thorburn, 1973; Gleeson et al., 1974; Diehl \& Day, 1974). Between Days 13 and 14 we observed significant and precipitous decreases in both the progesterone content of the corpora lutea and the proportion of cholesterol which was associated with cytochrome P450. These results, the fact that the proportion of cholesterol associated with $\mathbf{P} 450_{\text {scc }}$ did not decline when the corpora lutea were maintained by pregnancy and the fact that PGF-2 $\alpha$ treatmeni of gilts caused a concomitant decline in the cholesterol-associated $\mathrm{P}^{4} \mathrm{SO}_{\text {scc }}$ and in $\mathrm{CL}$ or plasma progesterone, suggest that the proportion of $\mathrm{P450}_{\text {scc }}$ bound to cholesterol is associated with functional luteolysis.

From Days 4 to 13 of the oestrous cycle $\mathrm{P} 450_{\text {scc }}$ is essentially saturated with cholesterol (over $90 \%$ bound), indicating that the supply of cholesterol to $\mathrm{P}^{450_{\text {scc }}}$ exceeds metabolism. 
Under these conditions cholesterol combination with the cytochrome does not provide a sensitive indicator of hormonal activation. However, the transition to a partly depleted state on Day 14 in association with a decline in metabolism strongly indicates a many-fold decline in the rate of combination of cholesterol with $\mathrm{P} 50_{\text {scc }}$. Since there is no significant change in total $\mathrm{P}_{450_{\text {scc }}}$ until Day 17, there is also a clear decline in total $\mathrm{P} 450_{\text {scc }}$-cholesterol complexes per corpus luteum between Days 13 and 14. Increases in progesterone secretion from Day 1 to Day 13 of the oestrous cycle and Days 16,17 and 20 of pregnancy seem, in part, to be attributable to changes in the total $\mathrm{P}^{4} 50_{\mathrm{scc}}-$ cholesterol complex level in the tissue. However, the exceptionally high activity on Day 10 must be due to some other aspect of progesterone synthesis which is not detected by this approach, e.g. turnover of the P450-cholesterol complex.

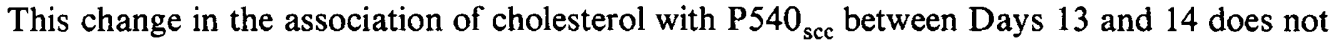
derive from a change in total mitochondrial cholesterol or luteal cholesterol esterase activity. No change is observed in the association of cholesterol with $\mathrm{P450}_{\mathrm{scc}}$ in disrupted mitochondria after Day 13. Disruption of Day 15 mitochondria leads to a release of cholesterol to the depleted sites on $\mathrm{P}_{450_{\text {scc }}}$ (Table 1), as has been reported for rat adrenal mitochondria (Jefcoate, 1975). Therefore, the control over cholesterol distribution requires intact mitochondria and presumably occurs, at least in part, within the mitochondria. The specific decline in cholesterol associated with $\mathrm{P}_{450_{\text {scc }}}$ is consistent with a controlled decline in the activity of the labile regulatory protein. That we observe this change at the point in the cycle where elevation of PGF- $2 \alpha$ has been observed (Gleeson \& Thorburn, 1973, Gleeson et al., 1974) and also as a direct response to PGF- $2 \alpha$ provides circumstantial evidence that PGF- $2 \alpha$ may depress the activity or synthesis of this protein.

The present studies of luteolysis appear to reflect a mixture of acute and chronic effects. There was a rise in the content of $P 450_{\text {scc }}$ both in mitochondria and luteal mass between Days 4 and 14, a decline on Days 15-17 to levels comparable to that on Day 4 and final reduction on

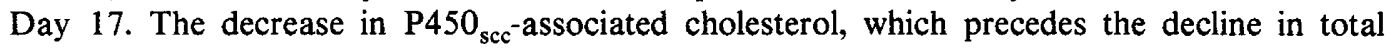
$\mathbf{P} 450_{\text {scc }}$, clearly parallels the changes observed in the adrenal gland when hormonal stimulation is removed by hypophysectomy. The changes in $\mathrm{P}^{4} 50_{\mathrm{scc}}$ described here are therefore consistent with direct block of $\mathrm{LH}$ stimulation by PGF-2 $\alpha$, e.g. antagonism of the LH stimulation of adenylate cyclase (Behrman et al., 1976).

In the pig, hypophysectomy after the preovulatory LH surge is followed by normal development of the corpus luteum until Day 10, after which the tissue begins to atrophy (du Mesnil du Buisson \& Leglise, 1963; Anderson, Dyck, Mori, Henricks \& Melampy, 1967). This sequence suggests that once initial LH stimulation has occurred, the corpora lutea no longer require pituitary support until Day 10. Lahau, Freud \& Lindner (1976) have reported that PGF$2 \alpha$ will antagonize LH-stimulated luteal activity in the rat but has no unilateral effect. Similarly, PGF-2 $\alpha$ seems to have no effect on the pig CL before Day 10 (Diehl \& Day, 1974; Douglas \& Ginther, 1975) perhaps due to a lack of dependence on luteotrophic support during this period.

In a previous study of $\mathrm{P}^{450_{\text {scc }}}$ in the corpora lutea of sheep during the oestrous cycle, Simpson, Jefcoate, Collett \& Land (1973) noted similar changes in total P450 ${ }_{\text {scc }}$ but no changes in the extent of combination of cholesterol with $\mathrm{P} 450_{\text {scc }}$. This need not be indicative of a different mechanism in the sheep since there are several occasions during surgical removal of the ovaries and isolation of mitochondria when cholesterol may redistribute and so remove differences of the type seen in the pig. However, extensive previous studies have shown that when $\mathrm{P}^{450_{\text {scc }}}$ is isolated in a cholesterol-depleted state in intact mitochondria the depletion has derived from a

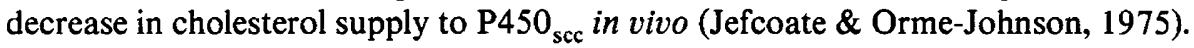

Based upon the present evidence, therefore, the sequence of events leading to and including luteolysis can be divided into three stages: (1) once formed, the porcine corpora lutea are free of luteotrophic support for up to 10 days (du Mesnil du Buisson \& Leglise, 1963; Anderson et al., $1967)$; (2) at the time of luteolysis, uterine PGF-2 $\alpha$ causes an initial decrease in cholesterol available to $\mathrm{P} 450_{\text {scc }}$, which results in the fall of progesterone production; and (3) there is a 
subsequent fall in $\mathrm{P}^{450_{\text {scc }}}$ levels accompanied by atrophy of other structural elements, leading to anatomical luteolysis. This sequence of events seems to be in better agreement with a loss of luteotrophic support due to a direct effect of a luteolysin on the corpora lutea than with a vasoconstrictor mechanism.

Research supported by the College of Agricultural and Life Sciences, University of Wisconsin, Madison, Wisconsin 53706; Public Health Service Training Grant 5T01-HD-0010410 from the National Institute of Child Health and Human Development; Grant 630-0505B from the Ford Foundation; NIH Grant AM-18565; Career Development Award CA 00250 from the National Cancer Institute. Departmental paper no. 709. We thank Susan Langan for determination of the cholesterol esterase activities.

\section{References}

Anderson, L.L., Dyck, G.W., Mori, H., Henricks, D.M. \& Melampy, R.M. (1967) Ovarian function in pigs following hypophyseal stalk transection or hypophysectomy. Am. J. Physiol. 21, 1188-1194.

Behrman, H.R., Grinwich, D.L. \& Hichens, M. (1976) Studies on the mechanisms of prostaglandin $\mathrm{F}_{2} \alpha$ and gonadotropin interactions on $\mathrm{LH}$ receptor function in corpora lutea during luteolysis. Adv. Prostaglandin Thromboxane Res. 2, 655-666.

Burstein, S. \& Gut, M. (1971) Biosynthesis of pregnenolone. Recent Prog. Horm. Res. 27, 303-350.

Coggins, E.G., Van Horn, D. \& First, N.L. (1977) Influence of prostaglandin $F_{2} \alpha$, dexamethasone, progesterone and induced corpora lutea on porcine parturition. J. Anim. Sci. 45, 754-762.

Diehl, J.R. \& Day, B.N. (1974) Effect of prostaglandin $\mathrm{F}_{2} \alpha$ on luteal function in swine. J. Anim. Sci. 39 , 392-396.

Douglas, R.H. \& Ginther, O.J. (1975) Effects of prostaglandin $\mathrm{F}_{2} \mathrm{\alpha}$ on estrous cycle or corpus luteum in mares and gilts. J. Anim. Sci. 40, 518-522.

du Mesnil du Buisson, F. (1961) Regression unilateeral des corps jaunes apres hysterectomie partielle chez la truie. Annls Biol. Anim. Biochim. Biophys. 1, 105112.

du Mesnil du Buisson, F. \& Leglise, P.C. (1963) Effect de l'hypophysectomie sur les corps jaunes de la truie. Resultats preliminaires. C. r. hebd. Séanc. Acad. Sci., Paris D 257, 257-261.

Dziuk, P.J., Phillips, T.N. \& Graber, J.W. (1964) Halothane closed circuit anesthesia in the pig. Am.J. vet. Res. 25, 1773-1775.

Garren, L.D., Gill, G.N., Masni, E. \& Waton, C.M. (1971) On the mechanism of action of ACTH. Recent Prog. Horm. Res. 27, 433-478.

Gleeson, A.R. \& Thorburn, G.D. (1973) Plasma progesterone and prostaglandin $\mathrm{F}$ concentrations in the cyclic sow. J. Reprod. Fert. 32, 343-344.

Gleeson, A.R., Thorburn, G.D. \& Cox, R.I. (1974) Prostaglandin $\mathbf{F}$ concentration in the utero-ovarian venous plasma of the sow during the late luteal phase of the oestrous cycle. Prostaglandins 5, 521-530.

Guthrie, H.D. (1975) Estrus synchronization and fertility in gilts treated with estradiol-benzoate and $\mathrm{PGF}_{2} \alpha$. Theriogenology 4, 69-75.
Guthrie, H.D. \& Polge, C. (1976) Luteal function and oestrus in gilts treated with a synthetic analogue of $\mathrm{PGF}_{2} \alpha$ (ICI 79,939) at various times during the oestrous cycle. J. Reprod. Fert. 48, 423-425.

Guthrie, H.D. \& Rexroad, C.E., Jr (1978) Secretion in vivo of progesterone by luteal tissue and of prostaglandin $\mathrm{F}_{2} \alpha\left(\mathrm{PgF}_{2} \alpha\right)$ by luteal and endometrial tissue of the pig. Abstracts, 70th Annu. Meeting Am. Soc. Anim. Sci., No. 370.

Halford, D.M., Wettemann, R.P., Turman, E.J. \& Omtvedt, I.T. (1975) Luteal function in gilts after prostaglandin $\mathrm{F}_{2} \alpha . J$. Anim. Sci. 41, 1706-1716.

Hermier, C., Combarnous, Y. \& Jutisz, M. (1971) Role of regulating protein and molecular oxygen in the mechanism of action of luteinizing hormone. Biochim. Biophys. Acta 244, 625-633.

Horton, E.W. \& Poyser, N.L. (1976) Uterine luteolytic hormone: a physiological role for prostaglandin $\mathrm{F}_{2} \alpha$. Physiol. Rev. 56, 595-651.

Ishikawa, T.T., Macgee, J. \& Morrison, J.A. (1974) Quantitive analysis of cholesterol in 5 to $20 \mu \mathrm{l}$ of plasma. J. Lipid Res. 15, 286-290.

Jefcoate, C.R. (1975) Cytochrome P450 of adrenal mitochondria spin states as detected by difference spectroscopy. J. biol. Chem. 250, 4663-4670.

Jefcoate, C.R. \& Orme-Johnson, W.M. (1975) Cytochrome P450 of adrenal mitochondria in vitro and in vivo changes in spin states. J. biol. Chem. 250, 4671-4677.

Jefcoate, C.R., Simpson, E.R. \& Boyd, G.S. (1974) Spectral properties of rat adrenal mitochondrial cytochrome P450. Eur. J. Biochem. 42, 539-551.

Kraeling, R.R., Barb, C.R. \& Davis, B.J. (1975) Prostaglandin-induced regression of porcine corpora lutea maintained by estrogen. Prostaglandins 9, 459463.

Lahau, M., Freud, A. \& Lindner, H.R. (1976) Abrogation by prostaglandin $F_{2} \alpha$ of luteinizing hormone stimulated cyclic AMP accumulation in isolated rat corpora lutea of pregnancy. Biochem. Biophys. Res. Commun. 68, 1294-1300.

Lowry, O.H., Rosebrough, N.J., Farr, A.L. \& Randall, R.J. (1951) Protein measurement with the Folin phenol reagent. J. biol. Chem. 193, 265-275.

Moeljono, M.P.E., Bazer, F.W. \& Thatcher, W.W. 
(1976) A study of prostaglandin $F_{2} \alpha$ as the luteolysin in swine. I. Effect of prostaglandin $F_{2} \alpha$ in hysterectomized gilts. Prostaglandins 11, 737-743.

Murphy, B.E.P. (1970) Methodological problems in competitive P-B technology. The use of Sephadex column chromatography to separate steroids. Acta endocr., Copenh., Suppl. 147, 37.

Nara, B.S. \& First, N.L. (1977) Effect of indomethacin and prostaglandin $\mathrm{F}_{2} \alpha$ in porcine parturition. $J$. Anim. Sci. 45, Suppl. 1, 191, Abstr.

Powell, W.S., Hammarstrom, S. \& Samuelsson, B. (1975) Occurrence of properties of a prostaglandin $\mathrm{F}_{2} \mathbf{\alpha}$ receptor in bovine corpora lutea. Eur. $J$. Biochem. 56, 73-77.

Simpson, E.R. \& Boyd, G.S. (1967) The cholesterol side chain cleavage system of bovine adrenal cortex. Eur. J. Biochem. 2, 275-280.

Simpson, E.R., Jefcoate, C.R., Brownie, H.C. \& Boyd, G.S. (1972) The effect of ether anaesthesia stress on cholesterol side-chain cleavage and cytochrome P450 in rat adrenal mitochondria. Eur. J. Biochem. 28, $442-450$.
Simpson, E.R., Jefcoate, C.R., Collett, R.A. \& Land, R.B. (1973) Cytochrome P450 activity in sheep corpora lutea during the oestrous cycle. J. Endocr. $58,493-502$.

Staigmiller, R.B., First, N.L. \& Casida, L.E. (1974) Compensatory growth and function of luteal tissue following unilateral ovariectomy during early pregnancy in pigs. J. Anim. Sci. 39, 752-758.

Steele, R.G.D. \& Torrie, J.H. (1960) Analysis of variance. I. The one-way classification. In Principles and Procedures of Statistics, Ch. 7, pp. 99-131. McGraw-Hill, New York.

Trzeyciak, W.H. \& Boyd, G.S. (1974) Activation of cholesteryl esterase in bovine adrenal cortex. Eur. J. Biochem. 46, 201-207.

Watson, J. \& Maule Walker, F. (1978) Progesterone secretion by the corpus luteum of the early pregnant pig during superfusion in vitro with PGF-2 $\alpha, \mathrm{LH}$ and oestradiol. J. Reprod. Fert. 52, 209-212.

Zar, J.H. (1974) Multiple comparisons. In Biostatistical Analysis, Ch. 12, pp. 151-182. Prentice Hall Inc., Englewood Cliffs, New Jersey.

Received 18 April 1979 